\title{
Structure of realised risks of projects for construction nuclear power plant by Rosatom State Corporation in 2010-2020
}

\author{
Ivan Voronkov ${ }^{1, *}$ and Roman Ostrovskii ${ }^{2}$ \\ ${ }^{1}$ Moscow State University of Civil Engineering (National Research University), 26, Yaroslavskoye \\ shosse, Moscow, 129337, Russia \\ ${ }^{2}$ ASE Joint Stock Engineering Company, 3, Svobody Sq., Nizhny Novgorod, 603006, Russia
}

\begin{abstract}
Rosatom State Corporation is one of the world leaders in the construction of nuclear power plant (NPP), keeping a ten-year portfolio of foreign orders at the level of 140 billion \$. Taking into account the long period of construction nuclear power plant, significant amount of capital investment, significant number of participants investment-construction project, critically important for constructer organizer to identify and consider possible risks of project implementation in time, developing and improving its management mechanisms. As a part of research risk analysis and systematization was performed, realized in the construction of nuclear power plants by domestic specialist in 2008-2020 (Novovoronezh NPP-2, Rostov NPP, Kursk NPP-2, Belarussian NPP, NPP Kudankulm, NPP ElDabaa, NPP Akkuyu, NPP Rooppur, NPP Paksh-2). Based on the analysis formed 8 risk families, determined shares of these groups in general registry. The revealed structure of realized risks demonstrates, that the largest share in general registry is made up of technical and organizational risks, which are systematically given insufficient attention by researches and construction organizers. Conducted research also allows us to draw a conclusion about the most common risk concerning late detection of complex conditions of the object placement site, which was implemented in five projects out of nine considered. The results of the accomplished research can be used in the development of modern nuclear power plant construction projects in Russia and abroad, which will have a positive impact on the competitiveness of domestic projects in the global nuclear power plant market and increase their profitability. The experience of nuclear power in terms of risk management can become a driver for fullscale improvement of organizational and technological approaches in the construction of unique buildings and structures in the future.
\end{abstract}

\section{Introduction}

Nuclear power construction is one of the drivers of the development of the domestic economy. By bringing up together more than 400 enterprises of various industries, State

\footnotetext{
* Corresponding author: voronkovie@mgsu.ru
} 
atomic energy Corporation «Rosatom» (State corporation, Rosatom) at the moment realizing 11 investment and construction projects [1,2] construction of nuclear power plants at the same tima, 7 of them are abroad. Annually declared volumes of the State Corporation's ten-year project portfolio remain quite high (more than 140 billions $\$$ for mid-2020), and Rosatoms`s foreign revenue for 2019 amounted more than 7 billion \$ [3] despite significant economic changes taking place in developed and developing countries.

According to some researchers' opinions, nuclear power construction is also one of the most effective means of building an innovative society in Russia [4] by the strengthening its leading positions in the world in the segment of construction and maintenance of nuclear energy facilities (OUAE) [5].

A significant contribution to the promotion of the Russian Federation interests in the global nuclear power plant market has made a significant devaluation of the national currency along with a scientific and technical potential of the domestic nuclear, which stimulated exports [6] and defind the high profitability of construction energy blocks NPP by Russian specialists. However, this factor is a time-limited and cannot be used in the long term.

In order to resolve this issue and in an effort to bring the efficiency and quality of its activities to the level of advanced international standarts, Rosatom imports the world s best management practices actively. Risk management technologies are no exception [7]. This direction of activity is carried out both at the level of the State Corporation, the Engineering division [8], and within each NPP construction project, which results in the formation and updating of risk registers [9], which are a source of extremely requested information about critical features of the implementation of NPP construction projects.

Each construction project of a modern nuclear power plant is unique. Despite the similarity in the power plant and in the set of basic equipment, the construction process of power units of various nuclear power plants differs significantly. The reasons for this are both the specific features of the power plant site, non-standard customer requirements, and the current political context [10]. The situation is even more aggravated in the context of the manifestation of differences in the legislation and the regulatory framework of the client country and the executing country. Multiplied by a long implementation period and a significant amount of capital investment [11], these features clearly demonstrate the high relevance of systematic improvement of all aspects of NPP construction project implementation without exception, including risk management.

Over the past decade, the scientific literature has repeatedly raised the theory and practice of large-scale implementation of risk management in the process of NPP construction management. Researchers have repeatedly decomposed risks in nuclear power construction into groups: emergency, financial and environmental [13] and categories: political and regulatory; technical; commercial and financial [13], however, in the overwhelming majority of studies, priority attention was paid to the analysis of financial and economic risks affecting the overall profitability of projects. At the same time, risks of a technical and organizational nature were not considered and were not studied in depth.

In addition to this, it should be noted that in the scientific literature studies that are devoted to the risk analysis that were realized on specific NPP construction projects and directly influenced the final result of construction are practically absent.

The lack of statistic and analytical materials on this issue in some ways reflects a shift in the attention of management structures from organizational and technological to financial and economic aspects of the implementation of projects for the construction of power units of modern nuclear power plants. The issues of technology and organization of construction and installation works are practically not discussed at the highest level and in most cases are solved at the level of specific performers, leading both to high material and labor costs 
for numerous local solutions of typical engineering tasks, and to the impossibility of accumulating structured experience available for any participant in the process.

This study aims to fill in the missing statistical information on the structure of risks that were implemented in most of the projects and that fundamentally influenced their profitability. Risks of a technological and organizational nature are of the greatest interest to the authors of the research.

\section{Materials and methods}

Traditionally, compiling a register of risks for NPP construction projects, risks are decomposed into groups by status and category. In the field of nuclear power construction, compiling a register of risks, depending on the State of the studied risk, one of the following statuses can be assigned:

- Active

- Temporarily closed

- Closed

- Excluded

- Not determined

- Implemented

By the middle of 2020, the risk register formed by the Engineering Company Atomstroyexport

(JSC ASE) for all projects implemented with its participation over the last 12 years includes information about more than 2,600 risks.

As part of the research analysis were exposed only implemented construction risks of the projects of NPP on the territory of the Russian Federation (Novovoronezh NPP-2, Rostov NPP, Kursk NPP-2) and beyond (Belarussian NPP, NPP Kudankulm, NPP ElDabaa, NPP Akkuyu, NPP Rooppur, NPP Paksh-2).

The classification of risks, carried out within the framework of the engineering division of State corporation «Rosatom», into categories implies assigning each of them to one of the 31 groups presented below. For the purpose of further analysis by the authors of the study, these groups were combined into families of risks (table 1).

Table 1. Risk groups and families of NPP power units construction.

\begin{tabular}{|c|c|c|}
\hline № & Group & Family \\
\hline 1 & Security risks & \multirow{5}{*}{$\begin{array}{l}\text { Socio-political and } \\
\text { ecological }\end{array}$} \\
\hline 2 & Environmental risks & \\
\hline 3 & Political risks & \\
\hline 4 & Social risks & \\
\hline 5 & Reputational risks & \\
\hline 6 & Legislative risks (Inc. in the field of environmental protection) & \multirow{4}{*}{ Legal and contract } \\
\hline 7 & Risks of licensing and permits of permits & \\
\hline 8 & Legal risks & \\
\hline 9 & Legal and contractual risks & \\
\hline 10 & Purchasing risks & \multirow{2}{*}{$\begin{array}{l}\text { Purchases and } \\
\text { supplies }\end{array}$} \\
\hline 11 & Delivery risks (Inc. design and manufacture of equipment) & \\
\hline 12 & Information technology and database management risks & \multirow{2}{*}{$\begin{array}{l}\text { Information and } \\
\text { databases }\end{array}$} \\
\hline 13 & Information risks & \\
\hline 14 & $\begin{array}{l}\begin{array}{l}\text { Risks of internal processes of project management and } \\
\text { organization of the company's work }\end{array} \\
\end{array}$ & \multirow{3}{*}{$\begin{array}{l}\text { Organizational and } \\
\text { managerial }\end{array}$} \\
\hline 15 & Project initiation and planning & \\
\hline 16 & Quality risks & \\
\hline
\end{tabular}




\begin{tabular}{|c|c|c|}
\hline 17 & Scoping and scheduling risks & \\
\hline 18 & Deadline risks & \\
\hline 19 & Project management risks & \\
\hline 20 & Risks of completion of construction, registration, commissioning & \\
\hline 21 & Human resources risks & \multirow{2}{*}{ Human resources } \\
\hline 22 & Personnel risks & \\
\hline 23 & $\begin{array}{l}\text { Commissioning risks ( Inc. interaction with the customer, } \\
\text { acceptance tests and the period of controlled operation) }\end{array}$ & \multirow{3}{*}{$\begin{array}{l}\text { Technical and } \\
\text { technological }\end{array}$} \\
\hline 24 & $\begin{array}{l}\text { Engineering risks ( Inc. development of design and estimate } \\
\text { documentation at the "Project" stage, development of working } \\
\text { documentation (WD)) }\end{array}$ & \\
\hline 25 & Risks of construction and installation works (CIW) & \\
\hline 26 & Financial risks & \multirow{6}{*}{$\begin{array}{l}\text { Financial } \\
\text { economic }\end{array}$} \\
\hline 27 & Commercial risks & \\
\hline 28 & Price risks & \\
\hline 29 & Economic / market risks & \\
\hline 30 & Macroeconomic & \\
\hline 31 & Marketing & \\
\hline
\end{tabular}

Formed families include a set of risks that are similar in content and sufficiently reflect certain aspects of the NPP construction project management. As of mid-2020, the general registry, complied by JSC ASE according to the announced projects, contains information on 147 realized risks of NPP construction over the past 12 years. The classification of these risks into families, taking into account the reasons for their occurrence and the nature of their manifestation, made it possible to obtain their following structure. (Table 2, figure 1).

Table 2. The number of realized risks of NPP power units construction by families and their share in the overall structure of risks.

\begin{tabular}{|c|l|c|c|}
\hline № & \multicolumn{1}{|c|}{ Family } & $\begin{array}{c}\text { The number of } \\
\text { realized risks }\end{array}$ & $\begin{array}{c}\text { Share of the family in the } \\
\text { overall structure of risks. (\%) }\end{array}$ \\
\hline 1 & $\begin{array}{l}\text { Technical and } \\
\text { technological }\end{array}$ & 45 & $30.61 \%$ \\
\hline 2 & $\begin{array}{l}\text { Organizational and } \\
\text { managerial }\end{array}$ & 29 & $19.73 \%$ \\
\hline 3 & Legal and contract & 26 & $17.69 \%$ \\
\hline 4 & Purchases and supplies & 22 & $14.97 \%$ \\
\hline 5 & Financial and economic & 14 & $9.52 \%$ \\
\hline 6 & Human resources and & 6 & $4.08 \%$ \\
\hline 7 & $\begin{array}{l}\text { Socio-political } \\
\text { environmental }\end{array}$ & 3 & $2.04 \%$ \\
\hline 8 & Information and databases & 2 & $1.36 \%$ \\
\hline
\end{tabular}




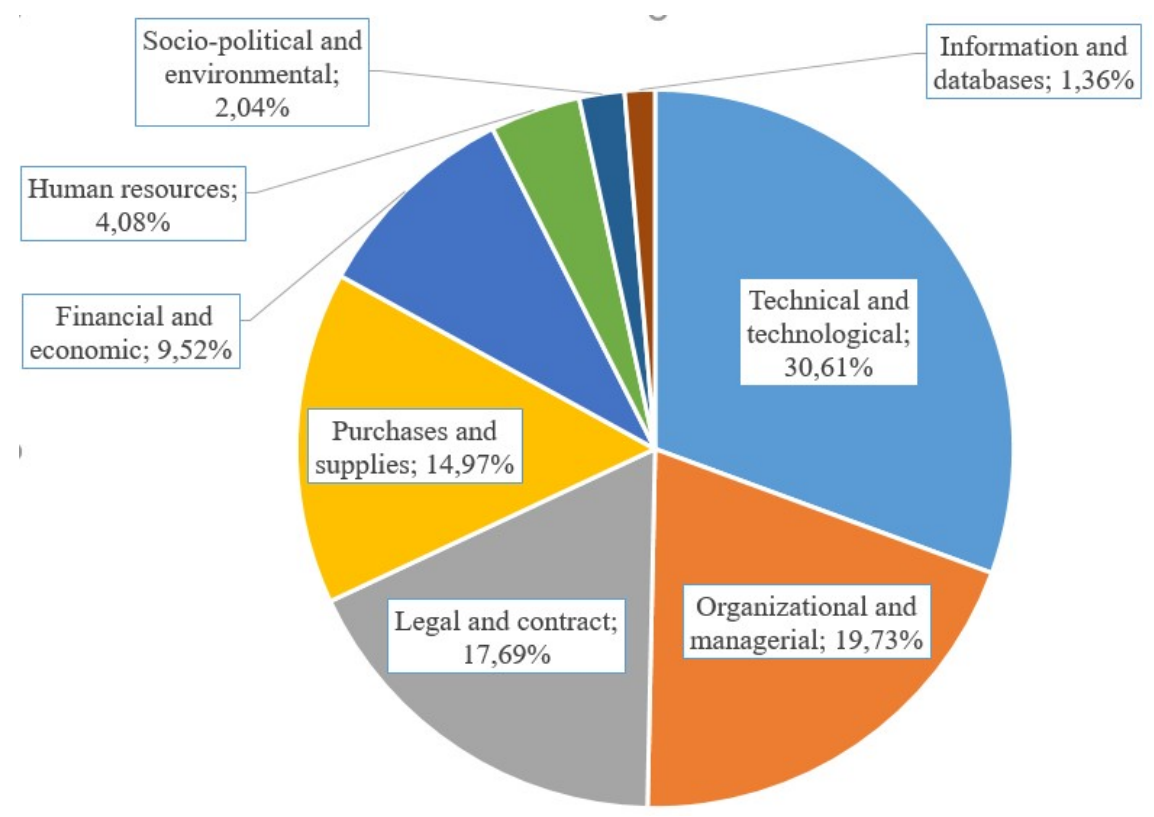

Fig. 1. Structure of realized risks of NPP power units construction.

\section{Results}

The performed analysis allows us to assert that the largest share in the structure of realized risks is the technical and technological family $(30,61 \%)$. At the same time, the total share of technical and technological and organizational and managerial families exceeds $50 \%$ that clearly demonstrates the urgent need to implement systematic work aimed at preventing the implementation of these risks, or reducing their negative impact on the ongoing NPP construction project.

According to the study authors opinion, in the field of nuclear power construction, there is currently an acute lack of attention of the organizational and management apparatus to the implementation of a coordinated and consistent policy of accumulating experience in solving specific engineering and technical problems and its unhindered transfer between projects [14].

The inability to quickly and efficiently import and test the accumulated technological experience during the construction of a nuclear power plant in most cases leads to the effectiveness of individual ICP participants [15], forced to spend additional resources on the search for technical or organizational and managerial solutions, and the entire project as a whole.

This problem is partially solved by introducing into the current process activities of offices of individual projects of the system of open meetings - "Obei" [16], as well as the implementation of the Production System "Rosatom" [17], but this program is not able to cover all problem areas. The technology transfer centers created in the nuclear industry are currently not endowed with the necessary powers and resources and, as a result, are not able to effectively solve the assigned tasks.

Separately, it should be noted that this problem acquires particular relevance in the context of the implementation of integrated project program management [18], when the conditions of communication and exchange of experience between all project participants is 
a fundamental condition for achieving a synergistic effect and largely determines the profitability of the project being implemented.

The comparatively small share of the socio-political and ecological family of risks revealed in the study is determined by the implementation of the investigated projects for the construction of nuclear power plants mainly in developing countries [19] and at sites adjacent to already functioning nuclear power generation facilities (substitution stations in the Russian Federation), which is determined on the one hand a sufficient level of loyalty of the local population (RF), and on the other hand, a relatively low level of development of legislation in the field of environmental protection and environmental literacy of civil society (international projects). However, this situation will inevitably change in the process of development of society, national legislation and adjustments in the foreign policy of the Russian Federation and potential customer countries. Already, there are sharp contradictions on this issue at the construction sites of the Hanhikivi-1 NPP in Finland and 5, 6 power units of the Paks NPP in Hungary. All of the above will automatically lead to an increase in the share of this family in the general risk register and will require prompt solutions to new problems.

It should also be noted that at present the family of risks "information and databases" accounts for only $1.36 \%$ of realized risks, however, the current digitalization of both technological processes of design, construction of nuclear power plants, and management processes predetermines the high promising relevance of activities on protection of information, copyright, as well as ensuring the safety of technological processes from outside interference. With a high degree of probability, it can be argued that the weight of this family in the general risk register will systematically grow as new digital technologies and automated systems are introduced into the construction and operation of nuclear facilities.

Along with the above-mentioned features of the current State of the domestic nuclear power construction, the study performed allows us to highlight a number of problematic aspects. An analysis of the frequency of manifestation of risk situations of an organizational and technological nature allows us to assert that one of the most frequently realized risks from the investigated ones is the risk of untimely detection of difficult conditions of the site of the facility location (Kursk NPP, Paksh NPP blocks 5,6, Rooppur NPP, Belarusian NPP, NPP "El-Dabaa",). The realization of this risk within the framework of each of the above projects required a set of compensating measures and affected the increase in the total resource and labor costs for projects (Table 3).

Table 3. Compensating measures and the consequences of realizing the risk of untimely identification of complex conditions of the site for the location of the facility for individual projects.

\begin{tabular}{|c|c|c|c|}
\hline Realized risk & Project & Compensating measures & $\begin{array}{l}\text { Consequences of } \\
\text { risk realization }\end{array}$ \\
\hline \multirow{3}{*}{$\begin{array}{l}\text { The risk of } \\
\text { untimely } \\
\text { identification of } \\
\text { difficult } \\
\text { conditions of the } \\
\text { site of the object } \\
\text { location. }\end{array}$} & Kursk NPP & $\begin{array}{l}\text { Adjustment of the project with } \\
\text { replacement for soil damage } \\
\text { with a sand-gravel mixture for } \\
\text { the use of soil piles. }\end{array}$ & \multirow{3}{*}{$\begin{array}{l}\text { Increase in terms } \\
\text { and value of work }\end{array}$} \\
\hline & $\begin{array}{l}\text { Paksh NPP power } \\
\text { units } 5,6\end{array}$ & $\begin{array}{lrr}\begin{array}{l}\text { Additional } \\
\text { engineering } \\
\text { laboratory research. }\end{array} & \begin{array}{r}\text { volume } \\
\text { surveys }\end{array} & \begin{array}{r}\text { of } \\
\text { and }\end{array} \\
\end{array}$ & \\
\hline & Rooppur NPP & $\begin{array}{lrr}\begin{array}{l}\text { Additional } \\
\text { engineering }\end{array} & \begin{array}{l}\text { volume } \\
\text { surveys }\end{array} \\
\text { laboratory research, } & \text { and } \\
\text { development } & \text { of } & \text { working }\end{array}$ & \\
\hline
\end{tabular}




\begin{tabular}{|l|l|l|l|}
\hline \multirow{2}{*}{ NPP "El-Dabaa" } & $\begin{array}{l}\text { documentation for soil } \\
\text { strengthening. }\end{array}$ & \multicolumn{2}{|c|}{} \\
\cline { 2 - 3 } & $\begin{array}{l}\text { Adjustment of the location of } \\
\text { power units, additional } \\
\text { engineering surveys and } \\
\text { laboratory studies. }\end{array}$ & \\
\cline { 2 - 4 } & Belarusian NPP & $\begin{array}{l}\text { Injection of concrete } \\
\text { compositions into karst areas } \\
\text { under the main structures. }\end{array}$ & Increase in value \\
\hline
\end{tabular}

Taking into account the circumstances of the realization of this risk, it should be noted that the greatest attention should be paid to it in the implementation of international projects within the framework of which there is a high probability of the impossibility of performing a wide range of engineering surveys at the site of the proposed NPP construction by Russian specialists. In some cases, there may be opposition from national administrative structures, which delay the processes of transferring the results of surveys carried out by foreign organizations to domestic specialists

Under the prevailing conditions, the experience of realizing this risk and measures to minimize its negative impact should be taken into account as a priority when making decisions on the conclusion of contracts (and its content) for the construction of NPP power units in the conditions of poorly studied characteristics of promising sites, as well as the current restrictions on the admission of Russian specialists and specialized organizations to perform engineering surveys.

\section{Conclusions}

Summing up the results of the study, it should be noted that despite the absence in the modern domestic scientific literature of studies in the field of risk management of an organizational and technical nature during the construction of nuclear facilities, this issue is extremely relevant. The classification of risk groups into families, carried out by the authors, made it possible to structure the realized risks of NPP structures and to assess the weight of each family in the general register.

The results of the performed analysis clearly demonstrate that more than half of all the risks that have been realized over the past 12 years in the construction of nuclear power plants by the efforts of domestic specialists are precisely technical, technological, organizational and managerial. This circumstance forces us to pay close attention to the management processes of individual stages of projects and the mechanisms for solving fundamental technological problems characteristic of most projects.

While positively evaluating the results of the implementation of the production system "Rosatom" at the enterprises of the State Corporation, it should be noted that the use of this tool does not allow to fully resolve the arising technical and organizational issues and contradictions. The digital transformation of the industry is becoming more and more relevant [19], the need to create conditions for the effective functioning of structural units that implement internal and external technology transfer.

Along with the above, it should be noted that the development of national legislation in the field of environmental protection, the growth of environmental radiation literacy [19] of the local population, a promising transition to large-scale automation of production, as well as a gradual decrease in the share of manual labor in nuclear power construction pose new challenges to the organizer of construction. among which the authors sweep aside the 
prospects for an increase in the share of socio-political, environmental, and informational risks possible during the construction of nuclear power plants.

As promising areas for further research, a separate analysis of the structures of realized risks within the framework of international projects and projects for the construction of replacement stations in the Russian Federation should be highlighted. This division will make it possible to identify the risks most often realized in unique conditions and to form an idea of the most effective strategy and tactics for the development of domestic nuclear power construction in the context of risk management.

\section{References}

1. A.P. Soloveva, V.V. Kharitonov, O.G. Shmakov, J. Izvestiya vuzov. Yadernaya Energetika 3, 52-62 (2018)

2. I.E. Voronkov, J. Bulletin of BSTU named after V.G. Shukhov 11, 137-45 (2018)

3. D.S. Panteley, J. Energy Policy 6(148), 42-9 (2020)

4. M.A. Balashova, I.Y. Naumenko, I.V. Cvigun, J. Baikal Research Journal 10(4) (2019)

5. V.P. Obolenskiy, J. Russian Foreign Economic Journal 3, 24-32 (2018)

6. P.G. Grabovy, V.V. Berezka, J. Reality: economics, management 3, 6-16 (2019)

7. N.Ya. Leont'ev, J. Economics and management: problems, solutions 5(1), 62-6 (2018)

8. A.A. Trohov, J. Vestnik of the Plekhanov Russian University of Economics 3(93), 829 (2017)

9. A.S. Marchenko, J. Russian Foreign Economic Journal 1, 29-39 (2020)

10. A.A. Morozenko, I.E. Voronkov, J. Industrial and civil construction 10, 74-9 (2014)

11. R.S. Iaresko, Ukraine J. Business Inform 6, 73-9 (2014)

12. A.I. Guseva, M.V. Koptelov, J. Regional economy, investment, innovation, socioeconomic development: Theory, methodology and concept of modernization, 138-47 (2013)

13. Y.V. Chernyakhovskaya, J. MIR (Modernization. Innovation. Research) 7.2(26), 38-47 (2016)

14. I.E. Voronkov, J. IOP Conference Series: Materials Science and Engineering 365, 062035 (2018)

15. V.G. Denisova, J. Standards and Quality 9, 70-4 (2019)

16. I.V. Solov'ev, J. Economics of sustainable development 3(35), 170-7 (2018)

17. I.E. Voronkov, J. IOP Conference Series: Materials Science and Engineering 869, 062026 (2020)

18. S.Z. Zhiznin, V.M. Timokhov, J. MGIMO Review of International Relations 4(43), 6473 (2015)

19. Z.O. Osmanova, J. Scientific Bulletin: finance, banking, investment 3(48), 159-67 (2015) 